\title{
INKONSISTENSI PENGATURAN PARATE EXECUTIE BERKAITAN OBYEK HAK TANGGUNGAN*
}

\author{
Oleh : \\ Ayu Putri Miranda Puri** \\ I Gede Yusa*** \\ Program Kekhususan Hukum Bisnis \\ Fakultas Hukum Universitas Udayana
}

\begin{abstract}
ABSTRAK
Dalam hal debitur cidera janji, maka terlebih dahulu akan diberi teguran kepada debitur untuk melunasi utangnya. Namun, apabila debitur tidak menanggapinya dapat dilaksanakan eksekusi langsung atas kekuasaan sendiri (parate executie). Parate executie merupakan sarana eksekusi termudah dan cepat bagi kreditur untuk pelunasan piutang manakala debitur cidera janji. Dalam Undang-Undang Nomor 4 Tahun 1996 Tentang Hak Tanggungan (UUHT) terjadi inkonsistensi terhadap mekanisme atau aturan formal dalam pelaksanaan parate executie obyek hak tanggungan itu sendiri. Inkonsistensi dalam peraturan tersebut dapat menciptakan ketidakpastian hukum dalam masyarakat. Tujuan dari penelitian ini adalah untuk mengetahui inkonsistensi pengaturan parate executie hak tanggungan dalam UUHT dan upaya mengatasi inkonsistensi terhadap pengaturan parate executie dalam UUHT. Metode yang digunakan adalah metode hukum normatif, dengan menggunakan pendekatan perundangundangan dan pendekatan analisis konsep hukum. Hasil dari penelitian ini adalah apabila dikaitkan antara ketentuan pada Pasal 6 dengan Penjelasan Umum angka 9 dalam UUHT bahwa Penjelasan Umum angka 9 UUHT tersebut tidak dapat dijadikan sebagai sandaran bagi materi pokok yang diatur dalam batang tubuhnya, karena penjelasan dalam undang-undang tidak mempunyai kekuatan mengikat dan upaya mengatasi inkonsistensi dapat dilakukan dengan cara penerapan asas lex
\end{abstract}

\footnotetext{
* Penulisan karya ilmiah yang berjudul Inkonsistensi Pengaturan Parate Executie Berkaitan Obyek Hak Tanggungan ini merupakan ringkasan diluar skripsi

** Penulis pertama dalam penulisan karya ilmiah ini ditulis oleh Ayu Putri Miranda Puri (1604552022) mirandapuri16@gmail.com

*** Penulis kedua dalam penulisan karya ilmiah ini ditulis oleh Dr. I Gede Yusa, S.H., M.H.
} 
posterior derogate legi priori dan penyempurnaan pengaturan melalui revisi terhadap UUHT.

Kata Kunci: Inkonsistensi, Parate Executie, Hak Tanggungan

\begin{abstract}
In the case of debtor is defaults, then a reprimand will be given to the debtor to repay the debt. However, the approval of the debtor does not respond to it, it can be carried out direct execution on creditor own control (parate executie). Parate executie is the easiest and fastest means of execution for creditor for repayment of debts when the debtor defaults. In Law Number 4 of 1996 on Mortgage (UUHT), there are inconsistencies in the formal mechanism or rules in implementation of parate executie mortgage itself. Inconsistency in these regulations creates legal uncertainly in the society. The purpose of this research are determine the inconsistencies in the arrangement of parate executie in Mortgage Act and efforts to overcome inconsistencies in the arrangement of parate executie in Mortgage Act. The method used in this research is a normative legal method, with the statute approach and legal concept analysis approach as an approach. The results of this research are if related to the provisions of Article 6 with General Explanation number 9 of UUHT that the General Explanation number 9 of the UUHT cannot be used as a backing for the subject matter arranged in the body of a law,

because the explanation in the law does not have binding power and efforts overcoming inconsistencies can be done by applying the principle of lex posterior derogate legi priori and improving settings through revisions to UUHT.
\end{abstract}

\title{
Key Words: Inconsistency, Parate Executie, Mortgage
}

\section{PENDAHULUAN}

\subsection{Latar Belakang}

Penggunaan tanah sebagai jaminan kredit didasarkan atas pertimbangan bahwa tanah paling aman dijadikan jaminan kredit karena mempunyai nilai ekonomi yang relatif tinggi. Selain itu, jaminan atas tanah lebih memberikan kepastian hukum dan perlindungan hukum bagi kreditur. Lembaga jaminan yang 
dianggap efektif oleh perbankan adalah tanah dengan jaminan Hak Tanggungan. Dengan demikian dapat mempercepat pelunasan piutang kreditur, selain itu lembaga tersebut digunakan untuk mengikat objek jaminan utang yang berupa tanah. Dengan berlakunya UUHT, maka hipotek yang diatur dalam KUH Perdata dan Creditverband untuk selanjutnya tidak dapat digunakan oleh masyarakat untuk mengikat tanah. ${ }^{1}$

Dalam pelaksanaan eksekusi hak tanggungan, apabila debitur cidera janji maka akan diberi teguran terlebih dahulu kepada debitur untuk melunasi utangnya. Namun, apabila debitur tidak menanggapinya dapat dilaksanakan eksekusi langsung atas kekuasaan sendiri (parate executie). ${ }^{2}$ Dipahami bahwa pelaksanaan eksekusi dengan parate executie merupakan cara termudah dan cepat bagi kreditur untuk pelunasan piutang manakala debitur cidera janji dibandingkan dengan eksekusi melalui bantuan atau campur tangan Pengadilan Negeri. Parate executie dikatakan sebagai langkah untuk mempercepat pelunasan piutang kreditur, karena kreditur sebagai pemegang hak jaminan dalam melaksanakan eksekusi tidak memerlukan titel eksekutorial yang artinya dapat melaksanakan eksekusi sendiri tanpa mempedulikan adanya kepailitan debitur karena debitur bersifat sparatis. ${ }^{3}$

${ }^{1}$ I Gusti Agung Bagus Hendra Praditya, 2017, "Akibat Hukum Likuidasi Bank Terhadap Keberadaan Akta Pemberian Hak Tanggungan (APHT)", Vol. 2, No. 2, Acta Comitas Jurnal Ilmiah Prodi Magister Kenotariatan, Fakultas Hukum, Universitas Udayana, Denpasar, h. 192.

2 Kadek Octa Santa Wiguna, 2017, "Pelaksanaan Eksekusi Hak Tanggungan Berdasarkan UU No. 4 Tahun 1996 Tentang Hak Tanggungan Atas Tanah Beserta Benda-Benda Yang Berkaitan Dengan Tanah Pada PT. BPR Partha Kencana Tohpati", Vol. 5, No. 5, e-journal Ilmu Hukum Kertha Semaya, Fakultas Hukum, Universitas Udayana, Denpasar, h.8.

${ }^{3}$ Sri Soedewi Masjchoen Sofwan, 1980, Hukum Jaminan di Indonesia, Pokok-Pokok Hukum Jaminan dan Jaminan Perorangan, Liberty Offset, Yogyakarta, h.33. 
Pelaksanaan parate executie sudah dilaksanakan sejak berlakunya UUPA sampai berlakunya UUHT. ${ }^{4}$ Setelah berlakunya UUHT, bank selaku kreditur cukup jarang mengajukan permohonan pelelangan kepada Kantor Lelang Negara berdasarkan Pasal 6 UUHT. Karena permohonan tersebut akan ditolak oleh Kantor Lelang Negara dengan alasan adanya Putusan Mahkamah Agung No. 3210 K/Pdt/1984 tanggal 30 Januari 1986 dan adanya Buku II Pedoman Mahkamah Agung Republik Indonesia yang menyatakan harus adanya fiat dari Ketua Pengadilan Negeri. Dengan adanya putusan MARI No. 3210 K/Pdt.G/1984 dan Buku II Pedoman Mahkamah Agung Republik Indonesia yang mengharuskan adanya fiat eksekusi melalui Pengadilan. Kenyataannya pihak kreditur dalam melaksanakan proses lelang tanpa melalui Pengadilan, sehingga berdampak mempengaruhi peminat pembeli lelang, sebab sering terjdi banyak hambatan pada saat pengosongan karena lelang tidak melalui Pengadilan. ${ }^{5}$ Apabila ditelusuri pengaturan parate executie dalam UUHT terdapat kerancuan, kerancuan tersebut terlihat jika ketentuan pada Pasal 6 UUHT dihubungkan dengan Penjelasan Umum angka 9 UUHT yang menjelaskan agar pelaksanaan parate executie didasarkan padal Pasal 224 HIR/Pasal 258 RBg yang dimana harus memerlukan fiat dari Ketua Pengadilan Negeri.

Adanya kerancuan atas pengaturan parate executie dan prakteknya yang dapat menganggu kepastian hukum bagi jaminan Hak Tanggungan. Berdasarkan uraian latar belakang

\footnotetext{
${ }^{4}$ Herowati Poesoko, 2013, Dinamika Hukum Parate Executie Obyek Hak Tanggungan, Aswaja Pressindo, Yogyakarta, h.4.

5 Putri Widiastriana, 2015, "Akibat Hukum Pelaksanaan Lelang Eksekusi Hak Tanggungan Yang Tidak Sesuai Dengan Hukum Positif Indonesia”, Jurnal Hukum Sarjana Imu Hukum, Fakultas Hukum, Universitas Brawijaya, Malang, h.2.
} 
tersebut, sekiranya penting untuk ditelaah lebih lanjut. Maka penulis akan mengkaji masalah yang berjudul "Inkonsistensi Pengaturan Parate Executie Berkaitan Dengan Obyek Hak Tanggungan".

\subsection{Rumusan Masalah}

1. Bagaimana inkonsistensi pengaturan parate executie hak tanggungan dalam UUHT?

2. Bagaimana upaya mengatasi inkonsistensi terhadap pengaturan parate executie dalam UUHT?

\subsection{Tujuan Penelitian}

Tujuan dari penelitian ini yaitu untuk mengetahui inkonsistensi pengaturan parate executie hak tanggungan dalam UUHT dan untuk mengetahui upaya mengatasi inkonsistensi terhadap pengaturan parate executie dalam UUHT.

\section{ISI MAKALAH}

\subsection{Metode Penelitian}

Metode

penulisan

dalam

penelitian

ini menggunakan metode penelitian hukum normatif yang meneliti hukum dari perspektif internal dengan obyek penelitiannya adalah norma hukum. ${ }^{6}$ Penelitian hukum normatif merupakan penelitian kepustakaan, yaitu terhadap data sekunder. Dalam penulisan ini menggunakan pendekatan perundang-undangan dan analisis konsep hukum.

\subsection{Pembahasan}

\subsubsection{Inkonsistensi Pengaturan Parate Executie Hak Tanggungan Dalam UUHT}

6 I Made Pasek Diantha, 2017, Metodelogi Penelitian Hukum Normatif Dalam Justifikasi Teori Hukum, Kencana, Jakarta, h.12. 
Secara etimologis parate executie berasal dari kata "paraat" yang berarti siap ditangan, sehingga parate executie dikatakan sebagai sarana eksekusi siap ditangan. ${ }^{7} \mathrm{Hal}$ ini dikarenakan oleh pelaksanaan parate executie yang tidak melibatkan debitur atau pemberi hak tanggungan dan tidak melibatkan Pengadilan dalam pelaksanaan penjualannya. ${ }^{8}$ Parate executie dikatakan sebagai eksekusi langsung oleh pemegang hak tanggungan tanpa melalui bantuan atau campur tangan dari Pengadilan Negeri, melainkan hanya melalui bantuan dari Kantor Lelang Negara saja, dengan kata lain parate executie dilakukan tanpa memerlukan fiat dari Ketua Pengadilan Negeri. Dalam Pasal 20 ayat (1) huruf a UUHT menyatakan bahwa apabila debitur cidera janji, pemegang hak tanggungan pertama mempunyai hak untuk menjual obyek hak tanggungan sebagaimana yang diatur dalam Pasal 6 UUHT yang berbunyi:

"Apabila debitur cidera janji, pemegang Hak Tanggungan pertama mempunyai hak untuk menjual obyek Hak Tanggungan atas kekuasaan sendiri melalui pelelangan umum serta mengambil pelunasan piutangnya dari hasil penjualan tersebut".

Berdasarkan bunyi pasal tersebut, hak kreditur dalam hal debitur cidera janji untuk menjual obyek Hak Tanggungan melalui lelang sudah diberikan oleh Undang-Undang sendiri kepada kreditur, dengan demikian eksekusi tersebut dapat dilaksanakan tanpa meminta persetujuan terlebih dahulu kepada debitur. Pasal tersebut memberikan pemahaman bahwa kewenangan menjual atas kekuasaan sendiri diberikan kepada pemegang hak tanggungan pertama, walaupun tidak

7 J. Satrio, 2004, Hukum Jaminan, Hak Jaminan Kebendaan, Hak Tanggungan, Buku II, PT. Citra Aditya Bakti, Bandung, h.276.

8 Teddy Anggoro, 2007, "Parate Eksekusi: Hak Kreditur Yang Menderogasi Hukum Formil (Suatu Pemahaman Dasar dan Mendalam)", Vol. 37, No. 4, Fakultas Hukum, Universitas Indonesia, Jakarta, h. 43. 
diperjanjikan dalam Akta Pemberian Hak Tanggungan. Inkonsistensi ini dapat menimbulkan ketidakpastian hukum dalam pengaturan parate executie.

Ketentuan lain dalam UUHT yang mencerminkan ketidakonsistenan dari pengaturan parate executie dalam mekanisme pelaksanaannya itu sendiri. Berdasarkan Penjelasan Umum angka 9 UUHT yang berbunyi:

"Salah satu ciri Hak Tanggungan yang kuat adalah mudah dan pasti dalam pelaksanaan eksekusinya, jika debitor cidera janji. Walaupun secara umum ketentuan tentang eksekusi telah diatur dalam Hukum Acara Perdata yang berlaku, dipandang perlu untuk memasukkan secara khusus ketentuan tentang eksekusi Hak Tanggungan dalam Undang-undang ini, yaitu yang mengatur lembaga parate executie sebagaimana dimaksud dalam Pasal 224 Reglemen Indonesia yang Diperbaharui (Het Herziene Indonesisch Reglement) dan Pasal 258 Reglemen Acara Hukum Untuk Daerah Luar Jawa dan Madura (Reglement tot Regeling van het Rechtswezen in de Gewesten Buiten Java en Madura)".

Berdasarkan ketentuan diatas dalam pelaksanaan parate executie yang dipandang perlu untuk mendasarkan pada Pasal 224 HIR atau Pasal 258 RBg yang menyatakan dalam pelaksanaan parate executie hak tanggungan hanya dapat dilakukan atas izin dari Ketua Pengadilan Negeri. Apa yang disebutkan dalam Penjelasan Umum angka 9 UUHT tersebut jelas tidak saja bertentangan dengan ratio legis dimuatnya ketentuan Pasal 6 dalam UUHT tersebut, tetapi juga telah menunjukkan sikap inkonsistensi dari pembentuk Undang-Undang yang telah memberikan kewenangan kepada kreditur atau pemegang hak tanggungan pertama untuk menjual obyek Hak tanggungan atas kekuasaan sendiri melalui 
pelelangan umum. ${ }^{9}$ Hal tersebut dikatakannya menunjukan sikap inkonsisitensi karena antara Pasal 6 UUHT dengan Penjelasan Umum angka 9 UUHT, yang mana di satu sisi dalam Pasal 6 UUHT mengatur parate execeutie dilaksanakan secara langsung tanpa campur tangan Pengadilan Negeri, namun di sisi lain dalam Penejelasan Umum angka 9 UUHT secara formil harus dilaksanakan dengan adanya fiat Pengadilan Negeri.

Dengan demikian jika dikaitkan antara ketentuan pada Pasal 6 dengan Penjelasan Umum angka 9 dalam UUHT yang mana bahwa penjelasan tersebut tidak dapat dijadikan sebagai sandaran bagi materi pokok yang diatur dalam batang tubuhnya. Menurut ahli hukum Remy Sjahdeini, penjelasan UndangUndang tidak mempunyai kekuatan mengikat, oleh karenanya penjelasan undang-undang tidak boleh bertentangan dan memberikan ketentuan tambahan di luar dari pada undangundang yang dijelaskannya. Sehingga jika dikaitkan dengan pelaksanaan parate executie berdasarkan Penjelasan Umum angka 9 UUHT tidak dapat digunakan sebagai sandaran terhadap pelaksanaan parate executie, karena penjelasan undang-undang bukanlah merupakan norma akan tetapi hanya sebuah tafsiran resmi dari materi tertentu. Selain itu, Penjelasan Umum angka 9 UUHT bukan merupakan penjelasan dari Pasal 6 UUHT dengan begitu pelaksanaan parate executie hak tanggungan tidak seharusnya memerlukan fiat Pengadilan Negeri dan tidak seharusnya menggunakan prosedur Hukum Acara Perdata, melainkan hanya dilaksnakan melalui pelelangan umum yang dilakukan oleh Kantor Lelang Negara. Hal tersebut diatur pula dalam Surat Edaran BUPLN No. SE-23/PN/2000

9 Yudhis Tira Cahyono, 2016, "Eksekusi Hak Tanggungan Yang Menggunakan Upaya Parate Eksekusi", Jurnal Hukum Magister Ilmu Hukum dan Kenotariatan, Fakultas Hukum, Universitas Brawijaya, Malang, h.17. 
menyatakan bahwa penjualan obyek hak tanggungan dilakukan dengan cara lelang dan tidak memerlukan fiat dari Pengadilan.

Jika parate executie masih harus melalui fiat dari ketua pengadilan, maka letak paraat-nya (siap ditangan) sebagai hak untuk menjual atas kekuasaan sendiri menjadi hilang. Sedangkan parate executie pada prinsipnya merupakan suatu pelaksanaan eksekusi yang disederhanakan tanpa melibatkan pengadilan. Jika dalam parate executie diharuskan untuk mendapatkan perintah berdasarkan penetapan/fiat Ketua Pengadilan Negeri, maka penjualan tersebut tidak menjadi berbeda dengan eksekusi atas dasar titel eksekutorial yang ada dalam Sertifikat Hak Tanggungan dan eksekusi putusan pengadilan yang telah berkekuatan hukum tetap. ${ }^{10}$

\subsubsection{Upaya Mengatasi Inkonsistensi Pengaturan Parate Executie}

Ketentuan pada Pasal 6 UUHT yang mengatur pelaksanaan parate executie tanpa memerlukan fiat Ketua Pengadilan Negeri, dengan Putusan Mahkamah Agung Republik Indonesia No. 3210 K/Pdt/1984 tanggal 30 Januari 1986 menyatakan bahwa dalam pelaksanaan parate executie harus didasarkan pada Pasal 224 HIR atau Pasal 258 RBg yang mana harus dengan fiat Ketua Pengadilan Negeri, hal ini merupakan inkonsisten dalam pengaturan parate executie. Inkonsisten ini menciptakan ketidakpastian hukum dalam masyarakat, khususnya terhadap kreditur pemegang hak tanggungan. Dengan demikian kiranya perlu dilakukan upaya untuk mengatasi inkonsistensi terhadap pengaturan parate executie, dengan cara-cara sebagai berikut:

10 Offi Jayanti, 2018, "Pelaksanaan Lelang Tanah Jaminan Yang Terikat Hak Tanggungan", Vol. 20, No. 3, Kanun Jurnal Imu Hukum, Fakultas Hukum, Universitas Diponegoro, Semarang, h. 464. 


\section{Penerapan Asas Lex Posterior Derogat Legi Priori}

Dalam menghadapi permasalahan inkonsistensi pengaturan, ada beberapa asas peraturan perundangan sebagai pedoman, yaitu:

a) Asas Lex superior derogate legi inferior

b) Asas Lex specialis derogate legi generalis

c) Asas Lex posterior derogate legi priori

Asas lex superior derogate legi inferior mengandung makna bahwa aturan yang lebih tinggi mengesampingkan aturan yang lebih rendah, pada asas lex specialis derogate legi generalis mengandung makna bahwa aturan hukum yang bersifat khusus mengesampingkan aturan hukum yang bersifat umum, dan sedangkan asas lex posterior derogate legi priori mengandung makna bahwa aturan hukum yang baru mengesampingkan aturan hukum yang lama. ${ }^{11}$ Berdasarkan konflik norma yang terjadi dalam pengaturan parate executie maka dapat diatasi dengan penerapan asas lex posterior derogate legi priori. Sebelum itu, harus ditentukan terlebih dahulu ketentuan hukum yang bersifat lex posterior dan ketentuan hukum yang bersifat legi priori. Menurut pendapat penulis, ketentuan Pasal 6 UUHT merupakan lex posterior, karena aturan tersebut sedangkan Putusan Mahkamah Agung Republik Indonesia No. 3210 K/Pdt/1984 tanggal 30 Januari 1986 merupakan lex priori. Secara sederhana hal ini berarti aturan yang paling baru (posterior) mengesampingkan aturan yang lama (priori), dengan asas ini maka aturan lama tidak lagi sebagai hukum ketika telah ada aturan yang baru. Terkait dengan hal tersebut Putusan Mahkamah Agung Republik Indonesia No. 3210 K/Pdt/1984 tanggal 30 Januari 1986 secara hukum telah digantikan oleh

11 Dudu Duswara Machmudin, 2003, Pengantar Ilmu Hukum: Sebuah Sketsa,Refika Aditama, Bandung, h. 70. 
undang-undang yang lebih baru, yaitu UUHT. Dengan demikian berdasarkan UUHT tersebut, pelaksanaan parate executie dapat dilakukan sendiri oleh pemegang hak tanggungan pertama secara langsung (Pasal 6 UUHT).

2. Penyempurnaan Pengaturan dengan Melakukan Revisi Terhadap UUHT

Upaya hukum yang harus dilakukan untuk menjadikan konsisten pengaturan parate executie adalah dengan melakukan penyempurnaan pengaturan dengan merevisi UUHT yang mengatur tentang pelaksanaan parate executie, karena dalam UUHT inkonsisten dalam mengatur pelaksanaan parate executie, berikut adalah alasan perlu dilakukannya revisi terhadap UUHT:

a) Inkonsistensi Ketentuan Pada Pasal 6 UUHT dengan Penjelasan Umum angka 9

Sebelumnya sudah dijelaskan bahwa pada Pasal 6 UUHT menyatakan bahwa apabila debitur cidera janji, pemegang hak tanggungan pertama dapat menjual obyek hak tanggungan atas kekuasaan sendiri melalui pelelangan umum, yang artinya tidak memerlukan adanya fiat dari Ketua Pengadilan Negeri dalam melelang obyek hak tanggung tersebut hanya cukup dilaksanakan melalui pelelangan umum. Namun, ketidakonsistenan dalam UUHT ditunjukkan pada Penjelasan Umum angka 9 yang menyatakan bahwa pelaksanaan parate executie harus didasarkan pada Pasal 224 HIR/Pasal 258 RBg yang berarti dalam pelaksanaan parate executie diperlukan fiat dari Ketua Pengadilan Negeri. 


\section{PENUTUP}

\subsection{Kesimpulan}

1. Inkonsistensi pengaturan dapat ditemukan pada Pasal 6 UUHT yang dikaitkan dengan Penjelasan Umum angka 9 UUHT. Pada Penjelasan Umum angka 9 UUHT menyatakan bahwa parate executie hak tanggungan didasarkan Pasal 224 HIR/Pasal 258 RBg, sehingga memerlukan fiat Pengadilan Negeri Hak tanggungan sementara seharusnya parate executie dapat dilaksanakan langsung melalui kantor lelang negara tanpa fiat Pengadilan Negeri.

2. Perlunya dilakukan upaya-upaya untuk membuat pengaturan parate executie dalam UUHT menjadi konsisten dengan cara: penerapan asas lex posterior derogate legi priori, dengan demikian aturan yang baru mengesampingkan aturan hukum yang lama sehingga aturan yang berlaku untuk mengatur parate executie adalah Pasal 6 UUHT dan upaya penyempurnaan pengaturan dengan melakukan revisi rerhadap UUHT.

\subsection{Saran}

1. Dalam hal mengindari inkonsistensi dalam UUHT mengenai pengaturan pelaksanaan parate executie obyek Hak Tanggungan hendaknya UUHT perlu untuk dikaji ulang agar tidak terjadi inkonsistensi yang menciptakan ketidakpastian hukum dalam masyarakat, khususnya terhadap kreditur pemegang hak tanggungan.

2. Hendaknya sandaran pelaksanaan parate executie didasarkan pada Pasal 6 UUHT, karena jka terjadi 
konflik norma di dalam peraturan tersebut dapat menerapkan asas lex posterior derogate legi priori, yang mengandung makna aturan hukum yang baru mengemsampingkan aturan hukum yang lama. Dengan demikian dala parate executie obyek hak tanggungan dilaksanakan tanpa persetujuan dari pemberi hak tanggungan dan tanpa memerlukan fiat Pengadilan Negeri.

\section{DAFTAR PUSTAKA}

\section{Buku-Buku:}

Diantha, I Made Pasek, 2017, Metodelogi Penelitian Hukum Normatif Dalam Justifikasi Teori Hukum, Kencana, Jakarta.

Machmudin, Dudu Duswara, 2003, Pengantar Ilmu Hukum: Sebuah Sketsa, Refika Aditama, Bandung.

Poesoko, Herowati, 2013, Dinamika Hukum Parate Executie Obyek Hak Tanggungan, Aswaja Pressindo, Yogyakarta.

Satrio, J., 2004, Hukum Jaminan, Hak Jaminan Kebendaan, Hak Tanggungan, Buku II, PT. Citra Aditya Bakti, Bandung.

Sembiring, Sentosa, 2008, Hukum Perbankan, Cet.II, CV. Mandar Maju, Bandung.

Sofwan, Sri Soedewi Masjchoen, 1980, Hukum Jaminan di Indonesia, Pokok-Pokok Hukum Jaminan dan Jaminan Perorangan, Liberty Offset, Yogyakarta.

\section{Jurnal Ilmiah:}

Agung Bagus Hendra Praditya I Gusti, 2017, "Akibat Hukum Likuidasi Bank Terhadap Keberadaan Akta Pemberian Hak Tanggungan (APHT)", Vol. 2, No. 2, Acta Comitas Jurnal Ilmiah Prodi Magister Kenotariatan, Fakultas Hukum, Universitas Udayana, Denpasar.

Anggoro, Teddy, 2007, "Parate Eksekusi: Hak Kreditur Yang Menderogasi Hukum Formil (Suatu Pemahaman Dasar dan 
Mendalam)", Vol. 37, No. 4, Fakultas Hukum, Universitas Indonesia, Jakarta.

Cahyono, Yudhis Tira, 2016, "Eksekusi Hak Tanggungan Yang Menggunakan Upaya Parate Eksekusi", Jurnal Hukum Magister Ilmu Hukum dan Kenotariatan, Fakultas Hukum, Universitas Brawijaya, Malang.

Jayanti, Offi, 2018, "Pelaksanaan Lelang Tanah Jaminan Yang Terikat Hak Tanggungan", Vol. 20, No. 3, Kanun Jurnal Ilmu Hukum, Fakultas Hukum, Universitas Diponegoro, Semarang.

Octa Santa Wiguna, Kadek, 2017, "Pelaksanaan Eksekusi Hak Tanggungan Berdasarkan UU No. 4 Tahun 1996 Tentang Hak Tanggungan Atas Tanah Beserta Benda-Benda Yang Berkaitan Dengan Tanah Pada PT. BPR Partha Kencana Tohpati", Vol. 5, No. 5, e-journal Ilmu Hukum Kertha Semaya, Fakultas Hukum, Univeristas Udayana, Denpasar.

Widiastriana, Putri, 2015, "Akibat Hukum Pelaksanaan Lelang Eksekusi Hak Tanggungan Yang Tidak Sesuai Dengan Hukum Positif Indonesia", Jurnal Hukum Sarjana Ilmu Hukum, Fakultas Hukum, Universitas Brawijaya, Malang.

\section{Peraturan Perundang-Undangan:}

Republik Indonesia, 1996, Undang-Undang Nomor 4 Tahun 1996 Tentang Hak tanggungan Atas Tanah Beserta Benda-Benda Yang Berkaitan Dengan Tanah, Lembaran Negara Republik Indonesia Tahun 1996, Nomor 42, Tambahan Lembaran Negara Nomor 3632.

Putusan Mahkamah Agung Republik Indonesia No. 3210 K/Pdt/ 1984 Tanggal 30 Januari 1986

Surat Edaran Badan Urusan Piutang dan Lelang Negara Nomor SE-23/PN/2000 Tentang Petunjuk Pelaksanaan Lelang Hak tanggungan. 